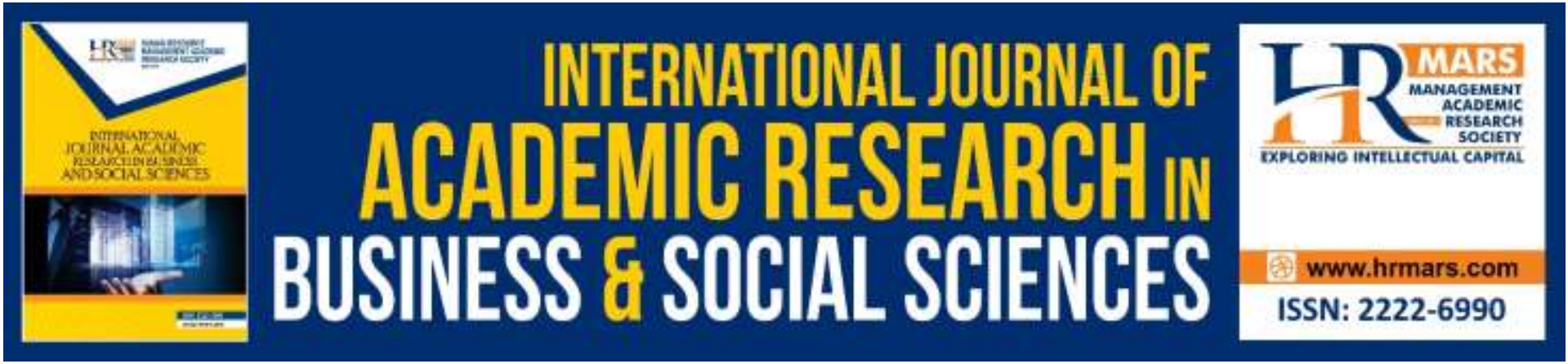

\title{
Development of a Mobile Application in Arabic Language Learning in Malaysia: An Overview
}

Hazrati Yahaya, Janudin Sardi, Mohammad Radzi, Ibrahim Youssef Abdelhamid, Fakulti Pengajian Islam

To Link this Article: http://dx.doi.org/10.6007/IJARBSS/v9-i7/6403

DOI: $10.6007 /$ IJARBSS/v9-i7/6403

Received: 22 May 2019, Revised: 12 June 2019, Accepted: 30 June 2019

Published Online: 26 July 2019

In-Text Citation: (Yahaya, Sardi, Radzi, Abdelhamid, \& Islam, 2019)

To Cite this Article: Yahaya, H., Sardi, J., Radzi, M., Abdelhamid, I. Y., \& Islam, F. P. (2019). Development of a Mobile Application in Arabic Language Learning in Malaysia: An Overview. International Journal of Academic Research in Business and Social Sciences, 9(7), 1366-1376.

\section{Copyright: (C) 2019 The Author(s)}

Published by Human Resource Management Academic Research Society (www.hrmars.com)

This article is published under the Creative Commons Attribution (CC BY 4.0) license. Anyone may reproduce, distribute, translate and create derivative works of this article (for both commercial and non-commercial purposes), subject to full attribution to the original publication and authors. The full terms of this license may be seen at: http://creativecommons.org/licences/by/4.0/legalcode

\section{Vol. 9, No. 7, 2019, Pg. 1366 - 1376}

Full Terms \& Conditions of access and use can be found at http://hrmars.com/index.php/pages/detail/publication-ethics 


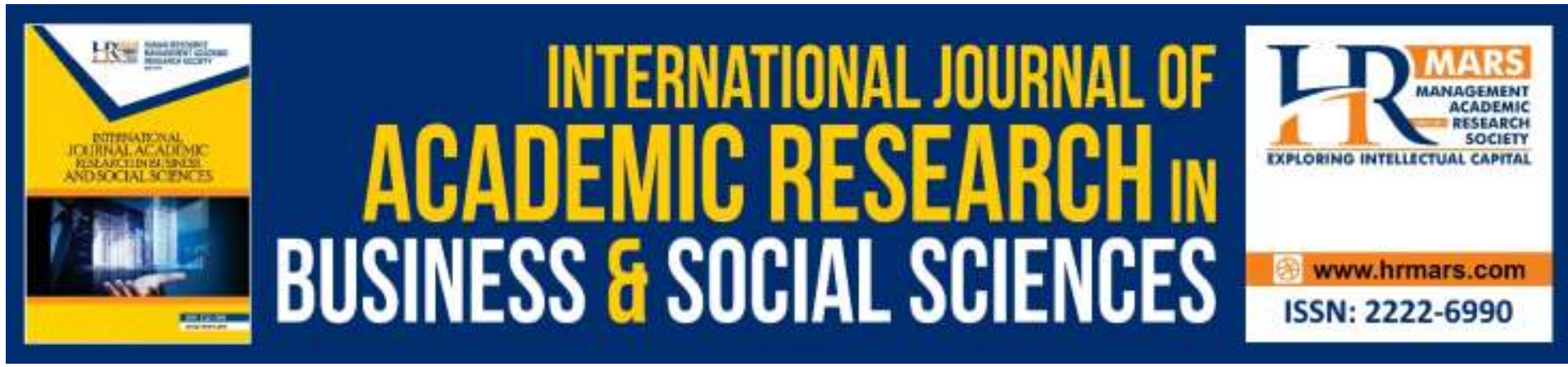

\title{
Development of a Mobile Application in Arabic Language Learning in Malaysia: An Overview
}

\author{
Hazrati Yahaya, Janudin Sardi, Mohammad Radzi, Ibrahim \\ Youssef Abdelhamid \\ Akademi Pengajian Bahasa, Universiti Teknologi MARA (UiTM) \\ Shah Alam, Selangor, Malaysia
}

Fakulti Pengajian Islam

Universiti Kebangsaan Malaysia (UKM), Bangi, Selangor, Malaysia

Email: hazratiy@gmail.com

\begin{abstract}
The rapid advancement of multimedia technology from day to day has led to the changing lifestyles of the present society. Multimedia technology plays a part in influencing the field of education and consequently has been integrated into the education system. Arabic language learning is also not exempted from the use of this technology. Through multimedia technology, Arabic language learning has become widespread with no limitations of time or place. In addition, the teaching and learning process of Arabic language will be easier and more fun. Therefore, this study aimed to explore the development of multimedia technology in the field of Arabic language learning especially in Malaysia. This study used the qualitative method by employing a descriptive analysis of previous studies. It is hoped that this study would serve as additional information that would assist any party in enhancing their efforts to improve students' mastery of Arabic language in the future.
\end{abstract}

Keywords: Development, Mobile Application, Arabic Language, Learning, Malaysia

\section{Introduction}

Recognising the importance of the change in teaching and learning designs for the $21^{\text {st }}$ century generation, the Ministry of Education Malaysia through the development of Malaysia Education Blueprint 2013-2025 has launched a $21^{\text {st }}$ century learning initiative nationwide. This $21^{\text {st }}$ century learning initiative outlines more dynamic learning features and meets the needs of today's students. In line with that, the learning initiative also emphasises some of the skills that need to be mastered including learning and innovation skills, information skills, and technology media. Undoubtedly, technology plays an important role in everyday life. By looking at the context of Arabic language education, mobile-based teaching aids provide many features and benefits to students and this is evidenced by past studies (Harry, 2017). Therefore, this study highlights past research related to the development of mobile applications that have been performed by previous researchers. 


\section{Research Methodology}

This study is a literature review aimed at exploring the development of mobile applications in Arabic language in Malaysia. There are several recent studies published between 2010 and 2019 available through online databases such as Science Direct, Springer Link, Google Scholar, and Research Gate. The researchers used keywords such as "mobile learning in Arabic language" and "development of mobile application" to identify relevant studies. The main criteria used by the researchers in looking for past studies are: i) research conducted in relation to the development of mobile applications; ii) published studies within 10 years between 2010 and 2019; and iii) studies that focus on learning Arabic language. The following studies related to the development of Arabic language mobile applications are categorised according to the study domain.

\section{Results}

The development of mobile applications for the Arabic language PdP has been done by previous researchers. This research is conducted to address the research problem mentioned above. Among the studies on mobile application development for Arabic PdP was by Dony et al. (2018), which was related to the development of an Arabic language learning app using the Object Oriented Programming (OOP) methodology. This app offers a method for learning Arabic reading that is equipped with learning levels as well as practice exercises. The use of this app among consumers, especially children, has had a positive impact on Arabic language reading skills. This is because the app is equipped with multimedia elements, such as graphics and audio that assist the child to successfully rework the audio he/she is listening to. However, the results showed that this application does not include vocabulary learning elements in the menus. Vocabulary learning needs to be incorporated into the app as it is the key to mastering reading skills. This app is depicted in Figure 1 below.
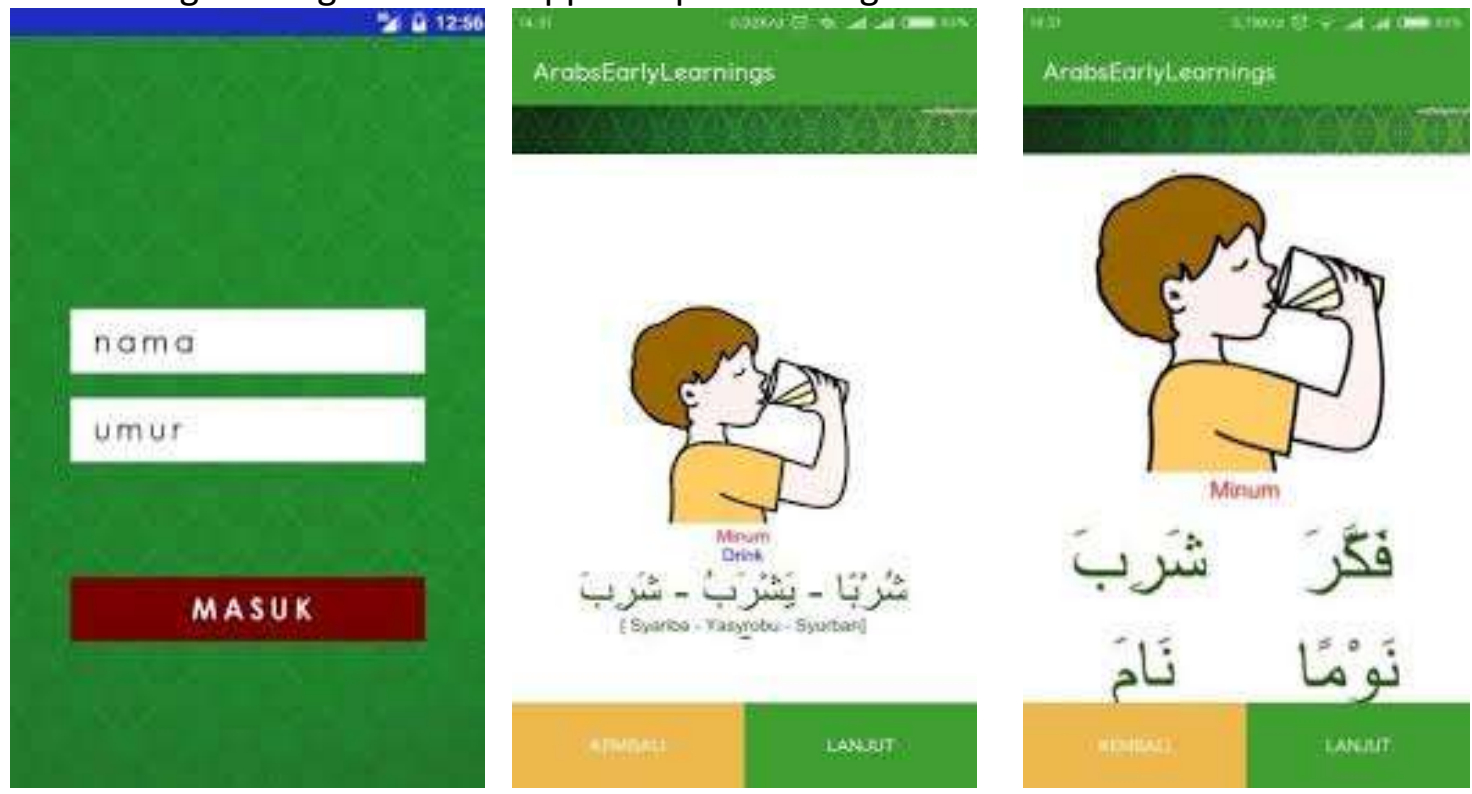

Figure 1: Mobile Application for Arabic Early Learning

Suhailah et al. (2015) examined the development of Arabic Language A-Grammar mobile application as shown in Figure 2. The application focuses on Arabic grammar because most students do not have the skills and understanding in learning Arabic grammar. This 
mobile app is expected to help students who are taking Arabic courses to practise and learn Arabic grammar whenever and wherever they want. Therefore, some multimedia elements, such as text, graphics, audio and video are integrated into this simple application with the aim of making learning more effective and engaging. However, appraisal components such as games, exercise activities, and quizzes are not implemented in this app. This assessment element is very important to assess the extent of the students' understanding of Arabic grammar.
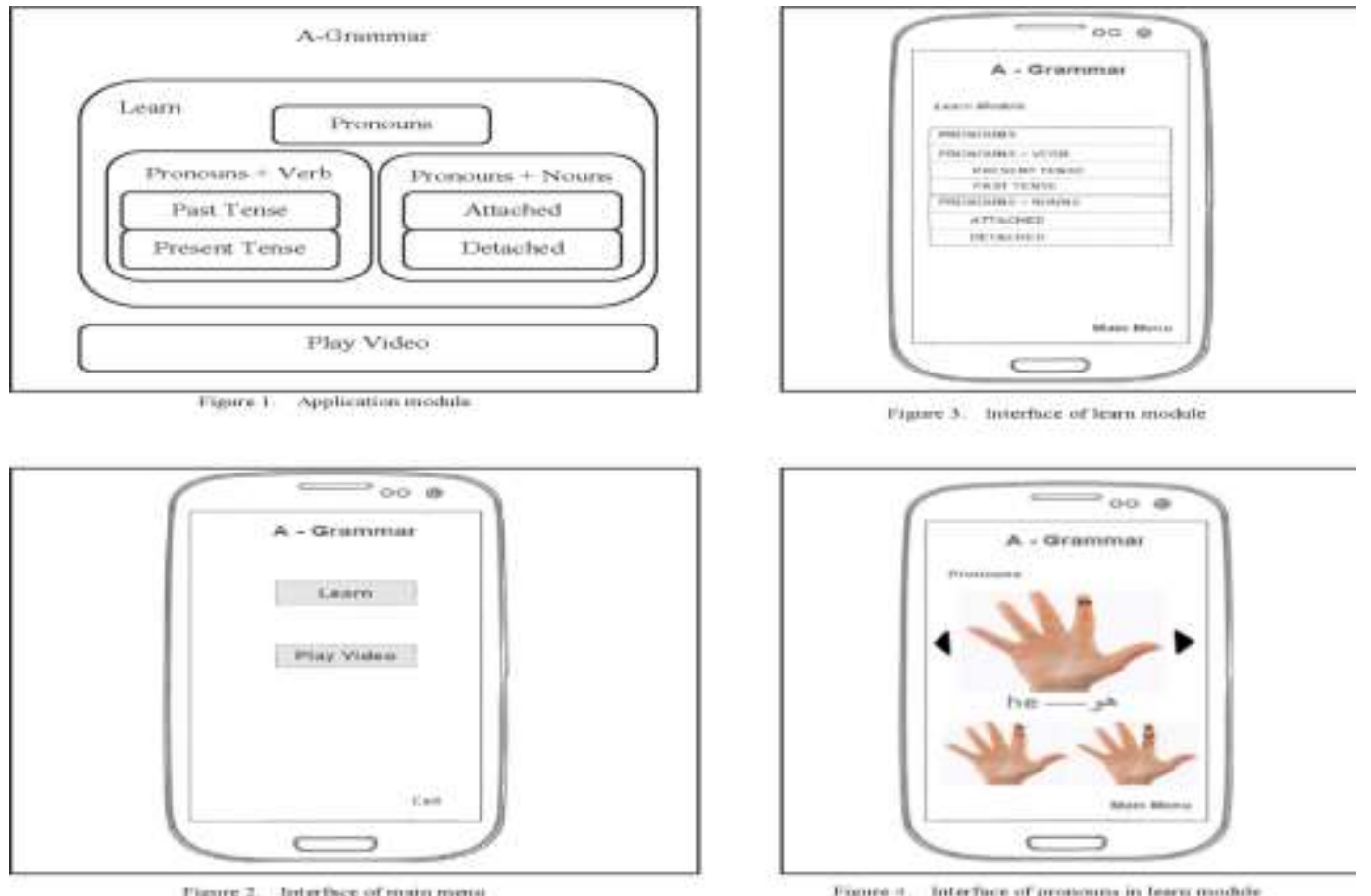

Figure 2 : Mobile Application of A-Grammar

In addition, Dihin et al. (2017) conducted a study on the development of an Arabic mobile app called the Tamrin Lughoh app. The content of the application is adapted from the Tamrin Lughoh Pondok Darussalam Gontor book. The purpose of this application is to help students who will study at UNIDA, Gontor, to master the Arabic language. The application has three main components, which are vocabulary, examples of construction of sentences based on the vocabulary presented, and training. These components are the strengths of this application. In addition, this app uses Android as the operating system. The findings showed that the application was developed with only $34.2 \%$ or seven of the 24 titles incorporated in the application. This application is limited to users from the Indonesian community only because the translation used in the application is in the Indonesian language. It is recommended that English translations are included to enable users from other countries to use the app to learn Arabic. This app is shown in Figure 3 below. 

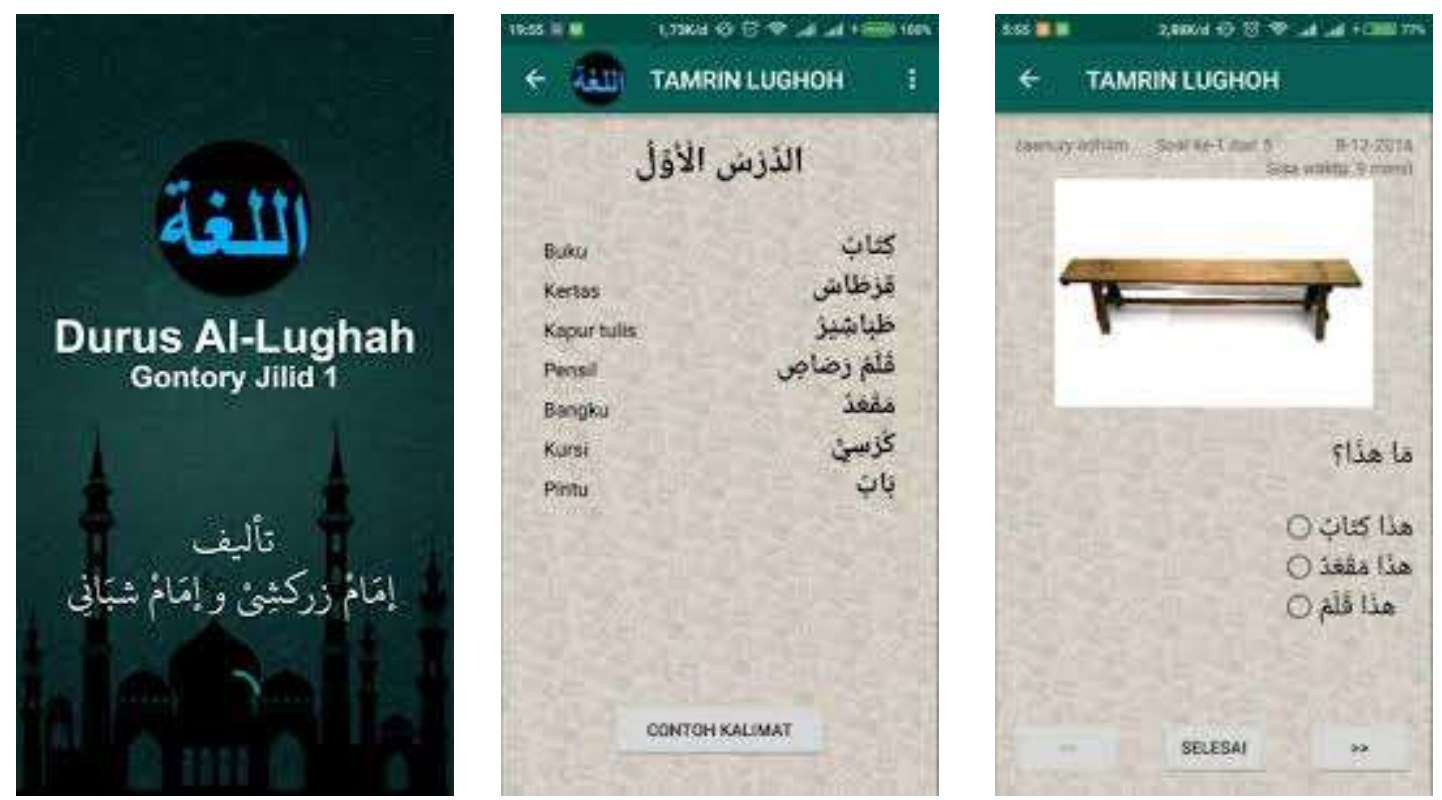

Figure 3 : Mobile Application of Tamrin Lughoh

Meanwhile, Abdul et al. (2016) focused on learning the Arabic language vocabulary using Android-based mobile applications. Therefore, the mobile application development was implemented using the Agile development method and the application is called Arabic Word Alert (AWA), built with SDK Android SD. This app includes word learning plans, word notification, word learning, and storage and assessment tests. The purpose of this application is to help students with vocabulary shortage problems. In addition, it can help resolve the issue of neglect of vocabulary learning that occurs in the Arabic language teaching and learning. Also, the application applies the concept of student-centered learning. This app is targeted for users who want to feed themselves in mastering the Arabic language vocabulary in relevant periods of time and in a consistent manner. This app not only offers users the meaning of the words in detail but it also provides important word information, such as word type, Arabic meaning, Malay meaning, and examples of usage. Word learning elements, such as instruction, quantity, duration, and strategy are also included in the app. The application is also capable of supplying at least 2000 basic words consisting of high-frequency words that are the core in the understanding of the students to deal with the situations of the language being used. The development of this mobile app is an effort and an alternative to empower the mastery of the Arabic language vocabulary among students. 

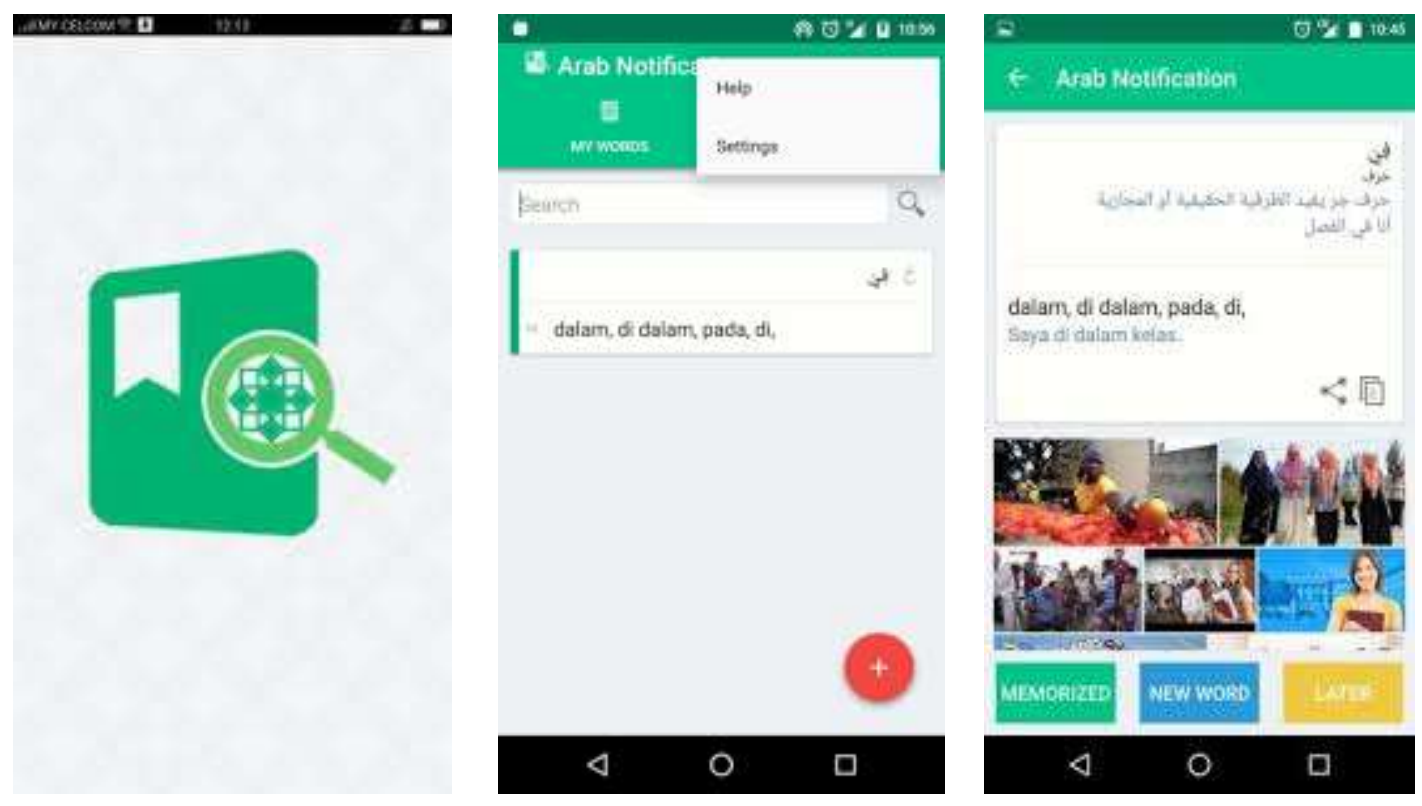

Figure 4 : Mobile Application for Arabic Word Alert (AWA)

In addition, A. Hussain et al. (2014) focused on Arabic language teaching for children with hearing disorders. This study used innovative approaches by developing mobile applications. This approach is believed to help educators teach deaf students to learn Arabic in a more practical way using numbers and colors. This app was developed using Eclipse IDE and Android SDK with Java and XML languages. This is an android app that can be used on smartphones or tablets. This app is available for free to users who want to learn Arabic. The interactions provided to the students are much more of a hand interaction and can indirectly solve their problems in learning. Students are provided with extensive menus of examples, training, and tests. The features contained in the menus enable students to get the right feedback and also identify what is right and wrong. This app is shown in Figure 5.
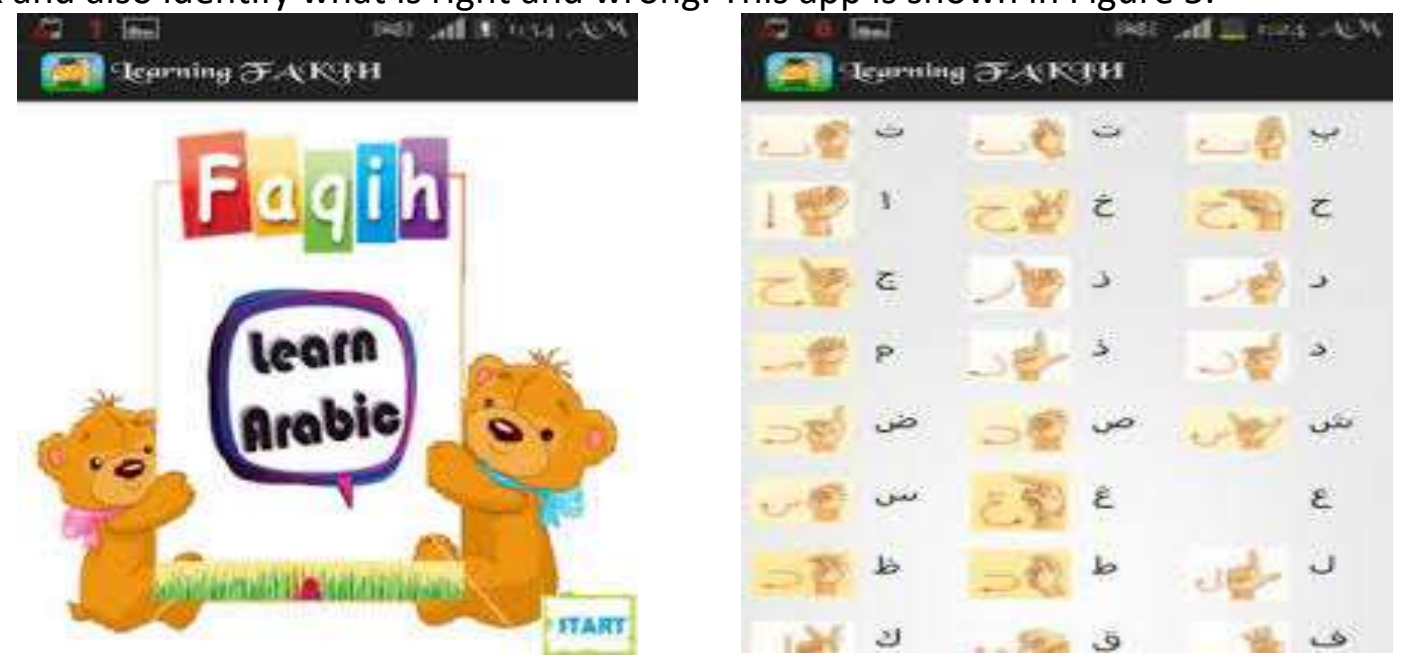

Figure 5 : Mobile Application for Faqih

Musliaza et al. (2016) focused on the study of a mobile application development known as the "Dialogue Trilogy Games" as shown in Figure 6. The purpose of this application is to solve the problems experienced by the students to master three languages simultaneously in their daily conversations. The three languages are Arabic, English, and 
Malay. Android platform is used to develop this app. Simulation and game strategies are applied in learning the dialogue skills. The dialogues are compiled in several situations with a three-way voice dictionary. This dialogue learning process is also complemented by visual interaction and reaction that can be seen through the target response and achievement of scores received. The content of the app is organised systematically and in an appealing form to create a relaxed and interactive atmosphere for students. As a result, the "Dialogue Trilogy Games" application is able to increase the motivation and solve problems experienced by students in mastering self-study skills. The app can be developed further from the aspect of content by adding more vocabulary and diversifying the situations.
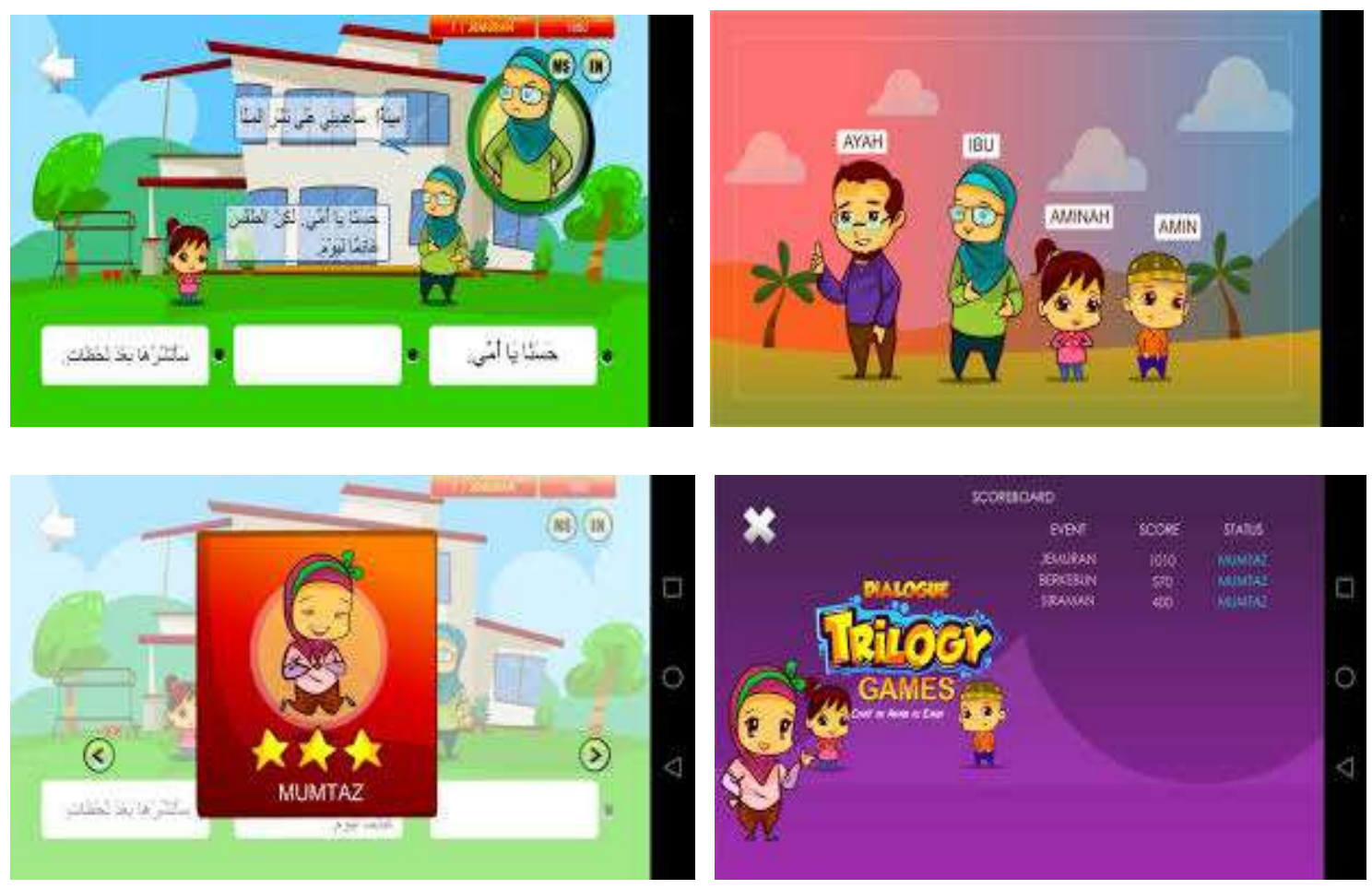

Figure 6: Mobile Application for Dialogue Trilogy Games

Furthermore, a study was conducted on an Arabic language mobile application development that uses a sense of comfort. It was developed by Ibrahim et al. (2019) using the Hanafin and Peck instruction design model that involved three phases, namely the analysis phase, the design phase, and the development and implementation phase. Elementary listening elements, such as songs, acting and language games are embedded in this app to make the Arabic teaching and learning process more interesting, effective and fun. In addition, the content is presented using interactive multimedia elements. However, this app is still not available in the Google Play Store, and hence, users cannot download it in the smartphone. This app is depicted in Figure 7. 

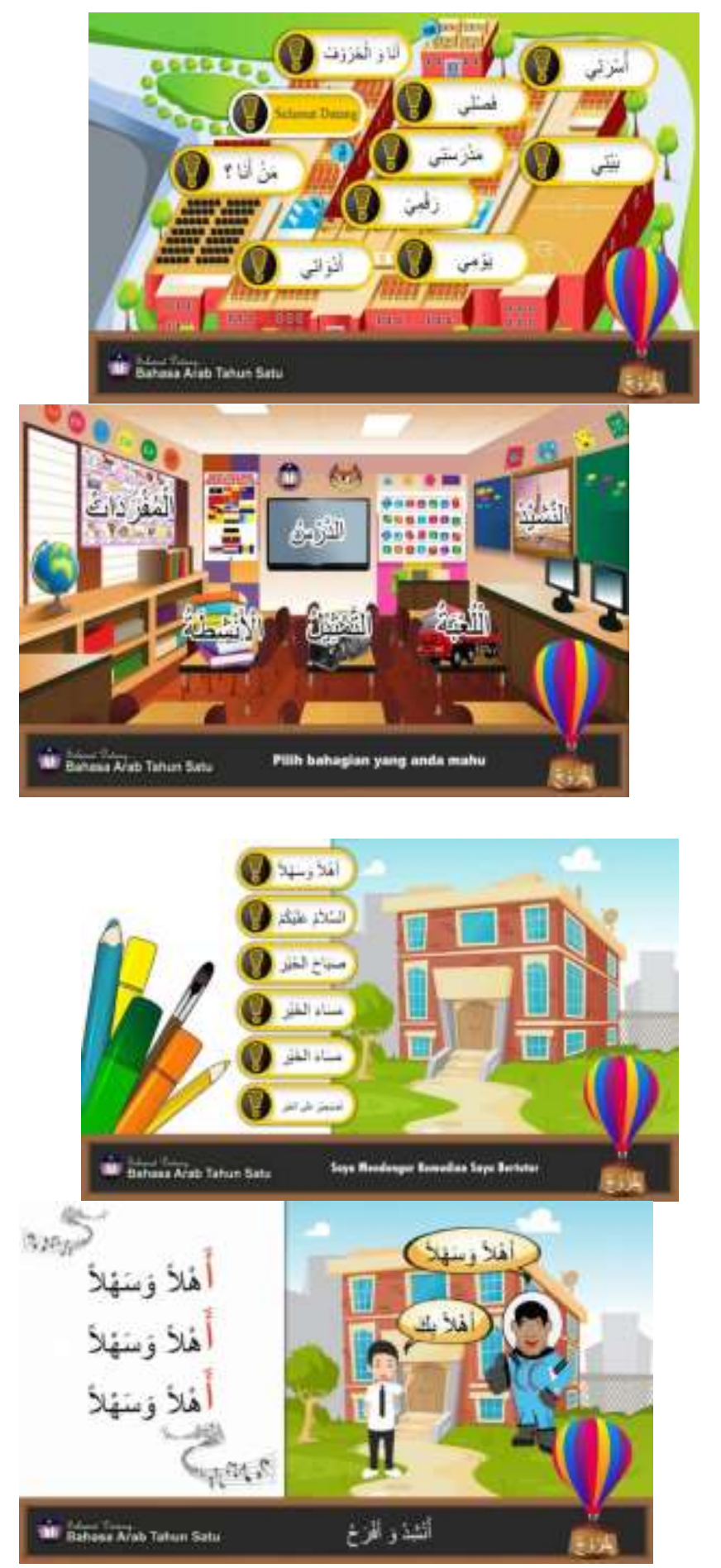

Figure 7 : Mobile Application for Bahasa Arab Tahun Satu

\section{Study Discussion}

The mobile applications used in learning are known as mobile learning ( $\mathrm{M}$-Learning) and it is not a new phenomenon. According to the study of Ahmad Sobri, S. (2010), the M-Learning method has long been practised by developed countries such as Europe. However, the level of M-Learning usage in Malaysia is still in moderation and it can be said that it is still new from the point of view of Nur Atikah et al. (2016). Even though M-Learning is still at a moderate level, the use of $\mathrm{M}$-Learning will become a compulsory requirement for students and trainers 
due to certain factors. Among these factors are the globally used, sophisticated, and inexpensive technologies and infrastructures. In addition, today's society is more information technology (IT) literate and almost a majority of them own and use a smartphone. In fact, every smartphone they own definitely comes with wireless or mobile technology (e.g. 3G, $4 G)$. At the same time, the requirements for $M$-Learning implementation have been met.

The effectiveness of m-learning in teaching and learning is undeniable and is evident in previous studies. In the study of Ardi \& Tasir (2008), there was a mention of note sharing among students, which was made easier with the availability of mobile devices, such as smartphones among the students. They do not have to sit in front of a personal computer to download the notes. Therefore, downloading of notes can be done anytime and anywhere. Furthermore, in a study on mobile devices in education by Triantafillou et al. (2006), it was shown that evaluations conducted through m-learning tests are more efficient and effective as they are more time-saving than paper-based tests. The study conducted by Alkhezzi and Al-Dousari (2016) showed the use of m-Learning in effectively improving students' understanding of vocabulary and grammar. This suggests that smartphones can be used in various ways to teach and learn vocabulary easily, either inside or outside the classroom.

There are many benefits to m-learning. According to Siraj (2004), the learning process can occur anywhere because wireless equipment such as PDAs, mobile phones, and handhelds are always with us as it is lightweight and the size is smaller than a laptop, making it easy for users to take it with them all the time. Therefore, indirectly, m-learning is no longer concentrated in tutorial rooms, lecture halls and so on. In addition, learning activities can be done during students' time or anytime. Thus, m-learning encourages lifelong learning in which everyone has the opportunity to use the m-learning app and not just limited to teachers and students. For example, housewives can access the m-learning app of interest while waiting for the return of their children from school. The m-learning is also a student-centered PdP approach that uses informal, independent, and collaborative learning (Yousuf, 2007).

Hence, the teaching and learning methods need to be combined with mobile technology in the m-learning environment to attract students. This is because they are currently exposed to a world of digital technology. Furthermore, most universities around the world have implemented certain courses using the m-learning method. For example, Sheffield University has implemented its study program using the m-learning system (Connell \& Lally 2002), while at the University of South Dakota, all legal and medical students use PDAs for their learning use (Goda et al., 2008). It can be concluded that the use of m-learning is indispensable as today's students and teachers are more technologically savvy, and to meet the demands of the seventh shift in Malaysia's Education Development Plan, the efforts of the government to enhance the use of Information and Communication Technology are being extended across institutions including state education institution. Hence, continuous efforts need to be made, which require the cooperation of all parties, especially the students and faculty to ensure that these efforts will achieve their goals.

\section{Conclusion}

Following the discussion of past studies highlighting the development of Arabic language mobile applications in Arabic language teaching and learning, it is clear that the use of Arabic language mobile applications can benefit both students and the general public who want to learn Arabic using the Arabic mobile applications developed by previous researchers. Integrating technology in language teaching and learning does not mean completely 
abolishing the traditional teaching methods that have been practised by the language teachers for so long. On the other hand, the use of technology is an innovative teaching process that combines traditional teaching techniques with a more creative way of delivering using technological instruments. Through the utilisation of technology in teaching activities, students can apply language skills, especially speaking skills as well as other language skills during the learning activities. However, the results of the research have shown that the mobile applications developed by the researchers mentioned above are still not commercialised within the Google Play Store or the Apps store. Therefore, future Arabic language mobile applications to be developed need to be commercialised so that the public can utilise the application.

\section{References}

Abdul, R., Zaini, S., Samsudin, K., Ashraf, E., Zaki, M. A. R., Khirulnizam, A. R.,Haron, M. H. \& Naqibah, M. (2016). Reka bentuk Aplikasi Pembangunan Kosa Kata Bahasa Arab, EProceeding of The Regional Conference on Civilization and Islamic Thoughts (ReCIT).

Sobri, A. S. (2010). Reka Bentuk Kurikulum M-Pembelajaran Sekolah Menengah: Teknik Delphi. Proceeding of Regional Conference on Knowledge Integration in Information and Communicating Technology, (pp. 652-665).

Alkhezzi, F., \& Al-Dousari, W. (2016). The Impact of Mobile Learning on ESP Learners' Performance. The Journal of Educators Online-JEO, 13(2): 73-101.

Azham, H., Nazean, J., Fazillah, M. K. \& Mohamad, N. (2014). mFakih: Modelling Mobile Learning Game to Recite Quran for deaf Children. International Journal on Islamic Applications in Computer Science and Technology, 2 (2): 8-15.

Dihin, M. \& Ahmad Farouk, A. (2017). Aplikasi Tamrin Lughoh (Pembelajaran Bahasa Arab)

Pondok Modern Darussalam Gontor Berbasis Mobile. Seminar Nasional Teknologi Informasi dan Multimedia, (pp. 241-246).

Fatma, Y. A., Hashmi, A. A., Musawi, A. A., \& Kazem, A. S. Q. (2016) Teachers' perceptions of the effectiveness of using Arabic language teaching software in Omani basic education. International Journal of Education and Development using Information and Communication Technology (IJEDICT), 12 (2): 139-157.

Goda, G., Kogure, Y., Shimoyama, Y., Kimura, M., \& Obari, H. (2008). Survey Research on Mobile

Harry, B. S., \& Rian, F. (2017). Prototype Development and Usability Evaluation of a Mobilebased Arabic Language Learning Application. Journal of Engineering and Applied Sciences, 12 (8): 1961-1967.

Ibrahim, Y., Kaseh, A. B., Suhaila, Z., Hazrati, Y. \& Bashasunnahar, P. (2018). Pembangunan Aplikasi Android Pembelajaran Asas Bahasa Arab. Journal ASEAN Comparative Education Research Journal on Islam and Civilization (ACER-J), 2(2): 39-59.

Conell, M. D., \& Lally, V. (2002). Developing, Sustaining E-Learning Communities. Paper presented at Symposium SCUTREA, 32nd Annual Conference. University of Stirling, Scotland, UK.

Azizol, M. (2011). Penggunaan Sistem E-pembelajaran Di Fakulti Pendidikan Universiti Teknologi Malaysia. Kertas Projek Sarjana Muda Sains Serta Pendidikan (Fizik). Fakulti Pendidikan, Universiti Teknologi Malaysia. 
Musliza, N. M., Ali, M. R.A., Jahari, A. W., Jusoh, M. H. \& Faizal, M. A. J. (2016). Pembangunan Perisian Permainan Simulasi Pertuturan Tiga Bahasa Secara Mudahalih. International Conference on Information Technology and Multimedia

Atikah, N. J., Jasmy, M. A. R. \& Atika, N. R. (2017). Pengadaptasian"E-Learning" Kepada "MLearning" Dalam Teknologi Pendidikan. Prosiding Seminar Pendidikan Serantau ke- $\quad$ VII. Fakulti Pendidikan Universiti Kebangsaan Malaysia Bangi, (pp. 572-580).

Fadilah, N., Aqsha, M., Harun, B. \& Akhma, N. (2015). Pembelajaran interaktif e- learning mencorakkan kemahiran berfikir aras tinggi. Proceeding the 7 th international workshop and conference of Asian studies on Islamic and Arabic education and civilization (poltan-ukm-polimed), (pp.1-8).

Phone Market for Mobile Learning in Japan. Paper presented at $5^{\text {th }}$ IEEE International Conference on Wireless, Mobile, and Ubiquitous Technology in Education (pp.194195). Beijing, China.

Saedah, S. (2004). Pembelajaran Mobile dalam Kurikulum Masa Depan. Jurnal Masalah Pendidikan, 27 (1): 128-142.

Suhailah, M. Y., Shuhada, S. N., Syahirah, A., Phaveena, P., Norlizawati, M. T. \& Rosmaiza, A. G. (2015). A-Grammar: Mobile Learning Foundation of Arabic Grammar Language with Multimedia Aided Approach. Proceedings International Symposium on Mathematical Sciences and Computing Research, (pp.30-35).

Syed Ardi, K. \& Zaidatun, T. (2008). Pembelajaran Masa Depan Mobile Learning (m-learning) di Malaysia. Prosiding Seminar Edupress Universiti Teknologi Malaysia, (pp.122-129).

Triantafillou, E., E. Georgiadou and Economides A. A., (2006). The design and evaluation of a computerized adaptive test on mobile devices. Computers and education, 50(4): 13191330. 